\title{
TOPICALITY OF CAREER GUIDANCE AT SCHOOLS FOR PROMOTING OF STUDENTS' PROFESSIONAL SELF-DETERMINATION
}

\author{
Evita Korna-Opincane, Irena Katane \\ Latvia University of Life Sciences and Technologies, Latvia \\ evita.korna@t2v.lv
}

\begin{abstract}
Professional self-determination is an important issue for anyone in the course of a lifetime. The dynamic nature of modern social and economic circumstances makes the issue even more topical. It determines the necessity to improve the career development support system currently existing in the field of education, where various specialists, by purposeful and systematic cooperation, help students in setting their career goals, understating the changeable working environment, seeing various alternatives and making deliberate career decisions. The career support is important as it helps learners choose a suitable professional sphere, profession and educational institution for continuation of their self-improvement upon acquiring of general secondary education. The aim of the research is to provide a scientific basis for topicality of career guidance implementation in school educational environment in order to promote the students' professional self-determination. In Latvia, a number of career development guidance systems, including counselling and student career support methods and forms are being created and approbated in the educational environment, focusing on the career support curriculum and principles, which would ensure a purposeful implementation of students' professional self-determination at schools.
\end{abstract}

Key words: career development, career guidance, pedagogical facilitation, psychological-pedagogical support, professional self-determination, educational environment.

\section{Introduction}

Nowadays, in our dynamic and rapidly changing world, a person must be a self-actualized and competitive personality capable of critical self-esteem and evaluation of personal abilities in order to find the optimal self-determination way for personal fulfilment. Learning to find the ways of making the most appropriate decisions, the learners must develop the ability to tolerate the uncertainty by creating the comprehension of changes taking place in the world, accepting these changes and understanding what to do in order to live in harmony with them rather than suffering from livelong discomfort and unawareness of what will happen with them, what should they do.

The sphere of education in general education schools is affected by social, economic and political changes taking place in the world. It is vital that youngsters understand their professional life path after the acquisition of general secondary education, while the teachers are to understand how they can help the upper school students in a purposeful, systematic, consistent way in line with the modern requirements. Therefore, any contemporary school must be aware of the possibilities to render support and assistance to young people in facilitation of their professional self-determination, as the practice shows that this process has mostly irregular nature, moreover, this process lacks the coordination with the professional plans of the students, the progress of their interests, educational institutions, programmes and the choice of profession.

To achieve the major changes both in the field of education and in the society, it is important to ensure the career support for the upper school students. Based on theoretical research, we can establish the theoretical insights related to the qualitative implementation of a career development support system in the sphere of education in terms of creation of professional selfdetermination among young people.

The aim of the research: to provide a scientific basis for the notion of career guidance and the topicality of its implementation in the educational environment for promoting the student professional self-determination.

\section{Materials and Methods}

This scientific article consists of the results of theoretical studies analysing the theoretical and practical insights of various scientists on career support in the sphere of education.

Research methods: study of theoretical literature; analysis and evaluation of scientific literature; reflection of personal pedagogical experience.

Within the context of career guidance, the theoretical basis for research of learners' professional self-determination is the following:

- Western theories of career self-management (Akkermans et al., 2013; Alhaddad, 2014; Hooley et al., 2013; King, 2001; King, 2004; Kossek et al., 1998; Kuijpers, Meijers, \& Gundy, 2011; Lengelle et al., 2014; Mackay et al., 2015; Paradnike, Endruiulaitiene, \& Bandzeviciene, 2016; Raabe, Frese, \& Beehr, 2006; Sturges et al., 2005).

- the theories of professional self-determination existing in Russian science (Дереча, 2005; Климов, 2010; Кузнецов, 2015; Лесовик, 2006; Муратова, 2008; Предигер, 2013; Пушкина, 2012; Воронина, 2013).

The results of theoretical studies serve as philosophical and methodological framework for 
creation of the career support system models, their empirical approbation and implementation in various general secondary education institutions in Latvia. The research is carried out within the project "Career support for young people at comprehensive and vocational education institutions $(2016-2020)$ " being held under the EU financed Operational programme "Growth and Employment".

In this paper the authors offer a part of their theoretical research results.

\section{Results and Discussion}

Insights of the theoretic research related to pedagogical support in the process of professional self-determination of students

The upper school students of general secondary education institutions must understand that the support rendered to them in the course of making their professional choice will help them in taking important decisions. Purposefully organised pedagogical support in the educational environment can ensure a systematic and consistent assistance for pupils who need it in the course of their professional selfdetermination, helping to understand themselves, as well as to become aware of the needs of the society and the surrounding environment. The research examines a number of studies on pedagogical support, its planning and implementing, as well as the studies on pedagogical support systems, on the necessity of the support in the process of professional selfdetermination and pedagogical facilitation, as well as the research on changes necessary during the training and education process for implementation of a pedagogical support in schools.

The necessity for a timely, systematic and wellorganised pedagogical support of students in the process of their professional self-determination

E. Voronina (Воронина, 2013) makes an important finding that the best results in the process of professional self-determination are ensured by a timely and methodologically correct pedagogical support. Considering the contemporary life and situation in education, the self-determination of a person is formed under contradictory circumstances, therefore, it is important to create a system which would promote the professional self-determination of pupils in terms of their individual traits, abilities, interests and regional demands. This process has the greatest importance at the age of $16-18$, when a person is in search of his or her personal identity, trying to answer such questions as: Who I consider myself to be? What kind of person am I? How do I find my niche in life? E. Voronina offers the principles of the arrangement of a pedagogical support system, providing for a cycle of preventive and operative studies focused on the introduction of the world of professions, understanding the personal treats of the pupils and the development of a realistic self-esteem, awareness of the demands existing in the modern job market and available education possibilities, the legislation in the field of technologies and professional activity, acquisition of skills in self-introduction and career planning.

I. Derecha (Дереча, 2005), providing a theoretical consideration of the necessity of the pedagogical support, emphasizes that the modern life requires that a pupil is able to make an immediate decision in case when a choice must be made. Therefore, the ability to make decisions in the changing social and economic environment helps pupils understand that the choice must be made among multiple options, which the youngsters must evaluate in terms of various situational aspects and choose the one that meets both their inward nature and the requirements of the surrounding environment.

Whereas, I. Lesovik (Лесовик, 2006) describes the system of pedagogical support, which is purposefully focused on the professional self-determination of an individual. The pedagogical support model elaborated is described as a system of psychological and pedagogical tools guiding the pupils in the process of their professional choice, developing their value system, abilities, self-awareness, enhancing their competitiveness and adaptation to rapidly changing job market conditions, as well as implementation of a professional career. This model provides for a beneficial cooperation among teachers, pupils and parents, which can be achieved by the purposefully selected means, diversified and variable forms of pedagogical support by ensuring a comprehensive approach to solving the pupils' professional selfdetermination issues.

At the same time, as it follows from E. Klimov (Климов, 2010), prior to the rendering support to young people in the process of their professional selfdetermination, it is important to understand the aim and the point of such support, to define the perspective of personal development depending on the choice of the profession and further professional education. The pedagogical support must be theoretically justified and systematically correctly planned. A. Muratova (Муратова, 2008) offers the stages of pedagogical support, such as: 1) the stage of screening determination of a problem; 2) the stage of searching looking for the problem causes together with a pupil; 3 ) the stage of coordination - planning of activities of a teacher and a pupil, defining the functions and the responsibility of each of them in solving the problems; 4) the stage of activity - the actions are taken by both the pupil and the teacher; 5) the stage of reflection mutual discussion of the achievements and failures 
on the previous activity stages, stating the ways and methods of problem solving or restating of problems for continuation of the activity.

The promoting role of a teacher in providing the career guidance to students

Validating the aspects of pupils' professional selfdetermination, many scientists and academic authors underline the importance of promoting or encouraging the function of a teacher as an essential activity principle in providing the career support, qualifying it as pedagogical facilitation (Кузнецов, 2015; Пушкина, 2012). The studies focus on two types of facilitation: social facilitation and pedagogical facilitation. With reference to the studies by O. Pushkina (Пушкина, 2012), the notion of pedagogical facilitation implies the purposeful process aimed at simplification of the educational process and enhancement of the efficiency of a teacher-pupil interaction contributing to professional self-determination and personal selfdevelopment, and promoting the self-organization and self-improvement skills.

To implement the process of education involving the personal development, the teacher can use various forms and methods in his or her work. $\mathrm{M}$. Prediger (Предигер, 2013) states that it is important to develop a subjective and reflexive experience as pupils are not ready for serious self-development, their self-development motivation is low. Therefore, the motivation for a successful professional selfdetermination can be only ensured by a purposeful pedagogical cooperation, which provides the support or assistance and which must be implemented in the form of interaction between a pupil and a teacher in the process of education.

The experience in implementation of career support is different throughout the world. This is the reason for the differences in types of career support services and the specialists who render support to pupils during the process of professional self-determination in educational environment. In Latvia, it is a Career Counsellor and a Teacher-Career Counsellor. Pedagogic guidance as a process is a complex of purposeful consecutive and constant activities, it is a system of career development support, which helps pupils understand the life situation occurred and ensures their self-development based on reflection of this situation. It creates various conditions for a pupil to take the optimal decisions in various life situations when a choice must be made, as well as to accomplish themselves in any social and economic conditions.

The educators' knowledge of student selfdetermination (including career self-determination) influences the pedagogical support in the context of career guidance at school (Thoma et al., 2002).
Facilitating student self-determination can be difficult (Thoma, Rogan, \& Baker, 2001; Thoma et al., 2002), therefore it is very important to include the career theories, educational content of student (including student with disabilities) career self-determination and career guidance in teacher education.

\section{Theoretical justification of career guidance in studies by foreign scientists}

The notion career, which is not so popular among Russian scientific researchers, is used within the context of professional self-determination. E. Klimov (Климов, 2010) characterized it as the achievement of the heights of mastery. However, at the same time, he notes that a professional life path is not striving for higher positions but moving up the scale of mastery and activity types, which is evaluated according to the efforts invested and the results achieved for the benefit of society.

Such terms as career guidance and career support are used in the studies carried out in Western Europe and other countries when speaking about the development of professional self-determination and career guidance skills.

Guidance is a multidimensional activity established in different contexts with varying meanings to different practitioners. In some literature, the terms educational, vocational, career guidance and career counselling are used interchangeably. The problem of definition is also compounded by the fact that different countries refer to persons performing guidance duties in different terms. Thus, we find reference to guidance counsellors (e.g. Flemish speaking Belgium, France, Greece, Iceland and Ireland), career education officers (Iceland), study counsellors (Finland), career path counsellors and school godmothers (Czech Republic), guidance teachers (Malta) and others (Sultana, 2004; cited from Debono et al., 2007).

The notion career support mostly implies a moral, mental support, while the notion career guidance is used to denote an advice, recommendation, the process of professional orientation, at the same also using such terms as occupational guidance and vocational guidance (Athanasou \& Van Esbroeck, 2008). Career guidance within the context of Western Europe and the world is theoretically and practically based on many various aspects, starting with the globalization and the world's social context, various degrees of education, types of activity and changeable job market, and up to the context of ethical values, cognitive thinking and other aspects, revealing the broadness and versatility of the term. The notion of career guidance, the same way as the notion career, can be viewed as an interdisciplinary construct combining the insights in the field of psychology, pedagogy, sociology, 
economics and other branches of science, as well as theoretical and empirical studies in the respective fields (Greenhaus \& Callanan, 2006). The notion career guidance is often used as an alternative for career education. However, it must be noted that career guidance is a more systematic process ensuring selfappraisal of a person, providing information about the world of work in order to simplify the development of an individual career and to train the decision-making skills. Career guidance can be considered as one of career education components (Greenhaus \& Callanan, 2006). In addition, the notion career guidance is often mixed with the notion career counselling, which is one of the ways for career support implementation during the process of career development (Spencer \& JoAnn, 2002). In the study by I. Luobikiene (Luobikiene, 2015), the notion of career guidance is defined as an individual help in making a reasonable choice of appropriate education and occupation possibilities, receiving the career education, career information and career counselling services.

As of 2006, when the notions career guidance, career guidance system, career development guidance, career development guidance system started to be used in the Latvian educational environment instead of the term professional orientation, the following elements constitute the system of career development support: informing, career education and career counselling. (Hansen, 2006). The notion of career support is defined in numerous scientific researches carried out in Latvia (Jaunzeme, 2011; Pāvulēns, 2016; Pranča, 2014; Pudule, 2013) by reviewing the notion within the context of a general education school, vocational and higher education, as well as within the context of occupation, associating the understanding of the notion with the issues of career education, career guidance and choice of profession. I. Mikelsone (Miķelsone, 2008) defined the notion career development guidance as a complex of activities with the aim to teach a person how to make decisions when choosing education or profession throughout his or her life by means of selfcognition.

Changes in implementing the career guidance in the Latvian educational environment

In the educational sphere in Latvia at present there has been highlighted the issue on both the development of competency-based learning curriculum and the possibilities to ensure career development support at educational establishments, which would be centred on pupils and the facilitation of their selfdetermination under the changing conditions of educational environment and labour market.

At the moment, not every educational institution in Latvia has a purposefully elaborated system of pedagogical support which would help young people in the process of their professional self-determination. Nevertheless, rendering support to learners in the process of their professional self-determination has been always a topical issue on the national scale, at the local government level and also at the school level. Currently the scientific environment of Latvia is concerned with elaboration of support models, which would be the most appropriate for every certain situation and ensure the efficient support of youngsters in making their decisions allowing for self-fulfilment in their chosen career area.

The process of pedagogic cooperation in education environment contributes to professional selfdetermination of a pupil, which is a very important aspect within the context of globalisation and changeable job market, therefore the above mentioned theoretical insights must be used as a philosophical and methodological basis for creation, approbation and implementation of the career development guidance system models in various general secondary education institutions of Latvia participating in the EU financed Operational programme "Growth and Employment" (Operational Programme..., 2014), the project "Career support for young people at comprehensive and vocational education institutions". Within this project, the availability of career support services for learners is planned to be increased in 308 general secondary education institutions and 20 vocational education institutions. It will be achieved by instituting a position of a Teacher-Career Counsellor or a Career Counsellor at every school involved in the project. Before the project was commenced in 2016, the career guidance for students was rendered by the respective supervising teachers, school administration and/or school psychologists within their competence. This project though implies a teamwork of various support specialists, including Career Counsellors and/ or Teachers-Career Counsellors. It has been observed that a number of schools have tried to systemise the availability of career guidance within their educational institutions, and in certain cases, it was also achieved by cooperation with local authorities. However, no conceptual and systematic coherency can be observed among the educational institutions, local governments and state authorities. The situation might improve after some of the career guidance models start working within the project "Career Guidance in General and Vocational Education Institutions", which would ensure a consistent and systematic approach to the career guidance for any student attending general or vocational education school. Consequently, further studies of career guidance availability to students within the project implementation period are required to identify the career guidance models and define the efficiency of such models in various local government educational institution of Latvia. It would allow to 
ensure the career guidance during the entire school period for learners of any age - from preschool age until acquiring secondary education. In order to ensure the local labour force in the educational and working environment, it is essential, when assessing the existing resources, their potential and weaknesses, as well as the developmental opportunities and challenges of sustainable society, to implement the conception of a local scale career support system, which would provide long-term return and, as a result of the implementation of which there would be facilitated the professional self-determination of young people.

The family is one of the main factors which influences the student career self-determination, therefore it is very necessary to cooperate with the members of student families (Epstein, 1992; Whiston $\&$ Keller, 2004). The authors' pedagogical experience testifies that Latvian schools have good practice in this field.

\section{Conclusions}

1. School years play an important role in the process of personal self-determination, when young people have to decide about their future professions and careers, by purposefully defining the stages of selfdevelopment.

2. To facilitate and promote the process of professional self-determination of youngsters, schools have to ensure the career support with the focus on rendering assistance, encouragment, promotion or facilitation, making young people feel secure about their future in the circumstances of unstable and changeable environment.

3. Special attention in the career support has to be paid to pedagogical and psychological support to ensure that a pupil can easier adapt to real social and economic environment, certain job market conditions, and be able to focus not only on the necessities in a certain situation but also to consider possible changes in the development of society and to adjust to the needs accordingly.

4. The studies by Russian scientists discuss such notions as pedagogical support and psychologically pedagogical support, including the term facilitation.

5. Scientific research carried out in Western Europe and other countries, when speaking about the professional self-determination in the educational environment, mentions the notion career support, which is theoretically and practically based on various aspects, revealing its broadness and versatility in terms of three functions: informing, career education and career counselling.

6. A number of notions exist in Latvian educational environment: career guidance, career guidance system, career development guidance, career development guidance system. These notions are closely interlinked and actually denote the same, i.e., the role and the function of teachers in the promotion and facilitation of the process of professional self-determination of pupils.

7. In Latvia, a number of career development guidance systems, including counselling and pupils' career support methods and forms are being created and approved in the educational environment, focusing on the career support curriculum and principles, which would ensure a purposeful implementation of pupils' professional self-determination at schools.

8. Upon starting the activity of Career Counsellors and Teachers-Career Counsellors in Latvian schools, various career guidance models, methods and forms are being created and tested in educational environment by focusing on the content and the principles of career guidance, which would systematically facilitate professional self-determination of students in schools and ensure the availability of career guidance for every learner during the entire school time.

9. It is also important to analyse various theoretical insights and, considering the results of approbation, to improve the career guidance system in Latvian schools and to understand the situation so that it is possible to provide recommendations aimed at ensuring more efficient career guidance in the educational environment.

10. These are the objectives of further practical researches which can be implemented considering the main theoretical insights analysed herein related to the career guidance during the process of professional self-determination of students, and combining both the theories of professional selfdetermination and pedagogical support existing in Russian science, and the Western theories of career self-management and career guidance theories.

\section{References}

1. Akkermans, J., Brenninkmeijer, V., Huibers, M., \& Blonk, R.B. (2013). Competencies for the Contemporary Career: Development and Preliminary Validation of the Career Competencies Questionnaire. Journal of Career Development, 40(3), 245-267.

2. Alhaddad, M. (2014). Career Self-Management in Ascription Culture. Doctoral Thesis of Philosophy. London: Brunel University. 
3. Athanasou, J., \& Van Esbroeck, R. (Eds.). (2008). Internationl Handbook of Career Guidance. Dordrecht: Springer Science + Business Media B.V.

4. Debono, M., Cammilleri, S., Galea, J., \& Gravina, D. (2007). Career Guidance Policy for Schools. Malta: Ministry of Education, Youth and Employment.

5. Epstein, J. (1992). School and family partnerships. In Alkin M. (Ed.), Encyclopedia of educational research. (pp. 1139-1151). New York: MacMillan.

6. Greenhaus, J., \& Callanan, G. (Eds.). (2006). Encyclopedia of Career Development. London: SAGE Publications Ltd.

7. Hansen, E. (2006). A Resource Handbook for Low-and Middle-Income Countries. Geneva: Interntional Labour Office.

8. Hooley, T., Watts, A.G., Sultana, R., \& Neary, S. (2013). The 'Blueprint' framework for career management skills: a critical exploration. British Journal of Guidance and Counselling, 41(2), 117-131.

9. Jaunzeme, I. (2011). Karjeras vadības un atbalsta sistēmas pilnveidošanas problēmas augstākajā izglītībā Latvijā. (Aspects of Improving Career Management and Support Systems in Higher Education in Latvia). Promocijas darbs. Rīga: Latvijas Universitāte. (in Latvian).

10. King, Z. (2001). Career Self-Management: a Framework for Guidance of Employed Adults. British Journal of Guidance and Counselling, 29(1), 65-78.

11. King, Z. (2004). Career Self-Management: Its Nature, Causes and Consequences. Journal of Vocational Behaviour, 65, 112-133.

12. Kossek, E.E., Roberts, K., Fisher, S., \& Demarr, B. (1998). Career self-management: A quasi-experimental assessment of the effects of a training intervention. Personnel Psychology, 51, 935-961.

13. Kuijpers, M., Meijers, F., \& Gundy, C. (2011). The relationship between learning environment and career competencies of students in vocational education. Journal of Vocational Behavior, 78, 21-30.

14. Lengelle, R., Meijers, F., Poell, R., \& Post, M. (2014). Career Writing: Creative, Expressive and Reflective Approaches to Narrative Identify Formation in Students in Higher Education. Journal of Vocational Behaviour, 85, 75-84.

15. Luobikiene, I. (2015). Career Guidance in Lithuania: Tradition or Fear of Change? In V. Dislere (Ed.), Proceedings of the 8th International Scientific Conference Rural Environment. Education. Personality, 15-16 May, 2015. (pp. 309-315). Jelgava: Latvia University of Agriculture.

16. Mackay, S., Morris, M., Hooley, T., \& Neary, S. (2015). Maximising the Impact of Careers Services on Career Management Skills A Review of the Literature. Derby: University of Derby, SQW, Skills Funding Agency.

17. Miḳelsone, I. (2008). Karjeras attīstība cilvēka dzīves ciklos. In Karjeras attīstības atbalsts: izglītība, konsultēšana, pakalpojumi (Career Development throughout Human Life Cycles. In: Career Development Support: education, consulting services) (9.-40. lpp.). Rīga: VIAA. (in Latvian).

18. Operational Programme "Growth and Employment". (2014). Riga: Ministry of Finance of the Republic of Latvia. Retrieved January 12, 2018, from: http://m.esfondi.lv/upload/Planosana/FMProg_270115_OP_ ENG_2.pdf.

19. Paradnike, K., Endruiulaitiene, A., \& Bandzeviciene, R. (2016). Career self-management resources in contemporary career frameworks: a literature review. Management of Organizations: Systematic Research, 76, 91-106.

20. Pāvulēns, J. (2016). Scientific and Everyday Understanding of the Notion of Career. In V.Dislere (Ed.), The Proceedings of the 9th International Scientific Conference Rural Environment. Education. Personality, 13-14 May, 2016. (pp. 211-308). Jelgava: Latvia University of Agriculture.

21. Pranča, V. (2014). Vidusskolēnu karjeras izvēli ietekmējošie faktori. In Studentu un maǵistrantu zinātniskās konferences raksti. 2014. gada 8. maijs (4.-7. lpp). (Factors Influencing High School Students' Career Choice. In Proceedings of the Scientific Conference for Students and Master's Degree Students). Jelgava: Latvijas Lauksaimniecības universitāte, Tehniskā fakultāte. Retrieved January 12, 2018, from: http://www. tf.1lu.1v/sites/tf/files/2016-12/tf_studentu_zinatniskas_raksti_2014_pedagogija.pdf. (in Latvian).

22. Pudule, G. (2013). Karjeras izglītības vad̄̄bas pilnveide vispārizglītojošajās skolās Latvijā (Improvement of the Management of Career Education in Comprehensive Schools of Latvia). Promocijas darbs. Rīga: Latvijas Universitāte. Retrieved January 12, 2018, from: https://dspace.lu.lv/dspace/bitstream/ handle/7/5221/39734promocijas_darbs_Guna_Pudule.pdf?sequence=1\&isAllowed=y. (in Latvian).

23. Raabe, B., Frese, M., \& Beehr, T.A. (2006). Action Regulation Theory and Career Self-Management. Journal of Vocational Behavior, 70, 297-11. 
24. Spencer, G.N., \& JoAnn, H.B. (2002). Career Development Interventions in the 21st Century. New Jersey: Merrill Prentice-Hall.

25. Sturges, J., Conway, N., Guest, D., \& Liefooghe, A. (2005). Managing the career deal: The psychological contract as a framework for understanding career management, organizational commitment and work behavior. Journal of Organizational Behavior, 26(7), 821-838.

26. Sultana, R. (2004). Guidance policies in the knowledge society-trends, challenges and responses across Europe. Luxembourg: Office for official publications of the European Communities.

27. Thoma, C.A., Nathanson, R., Baker, S.R., \& Tamura, R. (2002). Self-determination: What do special educators know and where do they learn it? Remedial and Special Education, 23(4), 242-247.

28. Thoma, C.A., Rogan, P., \& Baker, S. (2001). Self-determination in transition planning: Voices unheard. Education and Training in Mental Retardation and Developmental Disabilities, 34(1), 16-29.

29. Whiston, S.C., \& Keller, B.K. (2004). The influences of the family of origin on career development: A review and analysis. The Counseling Psychologist, 32, 493-568.

30. Воронина, Е.В. (2013). Педагогическая поддержка формирования готовности к профессиональному самоопределению школьников (Pedagogical support of the formation of readiness for the professional self-determination of students). Кониелm (04). Retrieved January 12, 2018, from: https://e-koncept. ru/2013/13081.htm. (in Russian).

31. Дереча, И.И. (2005). Педагогическая поддержка нравственного выбора стариеклассников 8 образовательном проиессе (Pedagogical support of the moral choice of high school students in the educational process). Автореф. канд. пед. наук. Омск: Омский государственный педагогический университет. Retrieved January 12, 2018, from: http://www.tmnlib.ru/jirbis/files/upload/ abstract/13.00.01/1348.pdf. (in Russian).

32. Климов, Е.А. (2010). Психология профессионального самоопределения (Рsychology of professional self-determination). 4-е издание. Москва: Академия. Retrieved January 12, 2018, from: http://www. academia-moscow.ru/ftp_share/_books/fragments/fragment_21192.pdf. (in Russian).

33. Кузнецов, Д.В. (2015). Психолого-педагогическая фасилитация старшеклассников (Psychologicalpedagogical facilitation of high school students). Образование и наука, 9(128), 167-175. Retrieved January 12, 2018, from: http://elar.urfu.ru/bitstream/10995/24491/1/iurp-2014-126-19.pdf. (in Russian).

34. Лесовик, И.В. (2006). Педагогическая поддержка старшеклассников в профессиональном самоопределении (Pedagogical support of high school students in the professional self-determination). Ростовский электронныци журнал, 18(140). Retrieved January 12, 2018, from: http://www.relga.ru/ Environ/WebOb-jects/tgu-www.woa/wa/Main?textid=1168\&level1=main\&level2=articles. (in Russian).

35. Муратова, А.А. (2008). Психолого-педагогическая поддержка профессионального самоопределения учащихся в предпрофильной подготовке (Psychological-pedagogical support of students professional self-determination in pre-profiling preparation). Интернет-журнал “Эйдос”. Retrieved January 12 , 2018, from: http://eidos.ru/journal/2008/0402-2.htm. (in Russian).

36. Предигер, М.Л. (2013). Педагогическое содействие формированию мотивации профессионального саморазвития у студентов вуза (Pedagogical facilitation of the motivation of professional selfdevelopment among university students). Фундаментальные исследования, 11(3), 574-577. Retrieved January 12, 2018, from: https://www.fundamental-research.ru/ru/article/view?id=33167. (in Russian).

37. Пушкина, О.В. (2012). Образовательная среда школь как основополагающее условие фасилитации профессионального самоопределения учашихся (The educational environment of the school as a fundamental condition for the facilitation of professional self-determination of students). Диссертация кандидата педагогических наук. Томск: Томский государственный педагогический университет. Retrieved January 12, 2018, from: http://www.dslib.net/obw-pedagogika/obrazovatelnaja-sreda-shkolykak-osnovopolagajuwee-uslovie-fasilitacii.html. (in Russian). 